Article

\title{
Impact of Gender and Expatriation Choice on Career Paths in Supply Chain Management: Evidence from Master of Science Graduates
}

\author{
Salomée Ruel ${ }^{1}$ (1) and Anicia Jaegler ${ }^{2, *}$ (i) \\ 1 MOSI-Sustainability Excellence Center, KEDGE Business School, 13009 Marseille, France; \\ salomee.ruel@gmail.com \\ 2 MOSI-Sustainability Excellence Center, KEDGE Business School, 75012 Paris, France \\ * Correspondence: anicia.jaegler@kedgebs.com
}

Citation: Ruel, S.; Jaegler, A. Impact of Gender and Expatriation Choice on Career Paths in Supply Chain Management: Evidence from Master of Science Graduates. Sustainability 2021, 13, 6907. https://doi.org/ $10.3390 /$ su13126907

Academic Editors: João Carlos de Oliveira Matias and Paolo Renna

Received: 7 May 2021

Accepted: 16 June 2021

Published: 18 June 2021

Publisher's Note: MDPI stays neutral with regard to jurisdictional claims in published maps and institutional affiliations.

Copyright: (c) 2021 by the authors. Licensee MDPI, Basel, Switzerland. This article is an open access article distributed under the terms and conditions of the Creative Commons Attribution (CC BY) license (https:/ / creativecommons.org/licenses/by/ $4.0 /)$.

\begin{abstract}
Zinn et al. (2018) and Esper et al. (2020) call for more research on gender diversity in Supply Chain Management, and our study responds to that call. We analyze the career path of 1081 international graduates from a higher degree program in Supply Chain Management from 2000 to 2017 to assess the impact of gender and expatriation choice on hierarchical progression. We explore two variables that may affect graduates' career paths, namely, their gender and their expatriation choices, and compare their relative importance. Our analysis shows that there were, on average, $33.5 \%$ women recruited in the MSc and that this has not significantly changed over the years. It also shows that gender significantly influences the number of years spent at each level in the career hierarchy and the level reached. Regarding expatriation choice, this variable has some significant impacts on career progression. Finally, statistics indicate that gender has a far greater influence on career progression than expatriation choice. Overall, this study proves the difficulties for women in enjoying the same career progression as men in the field of Supply Chain Management.
\end{abstract}

Keywords: gender diversity; expatriation; supply chain management; career paths

\section{Introduction}

McKinsey \& Company (Paris, France) has worked since 2007 on a program entitled Women Matter, and this has generated several reports. The 2010 report [1] addresses the proportion of women in decision-making bodies and boards of managers worldwide. In the manufacturing industry, women made up $6 \%$ of the boards of directors and $10 \%$ of decision-making bodies, while in the transport sector, they made up $9 \%$ in both categories.

Over ten years later, the global situation is not very different. If we look at the Supply Chain Management (SCM) function, particularly in the production and transport sectors, recent data still show the need to include more women. In fact, the SCM function is known by professionals as one of the least feminized company management functions.

Many recent reports from consulting firms highlight this gender gap. For example, the World Economic Forum [2] highlights that in retail most shop floor workers are women-a situation that cannot be observed at the upper levels of the hierarchy. McKinsey \& Company also points out this gender gap. In 2010, the consulting firm highlighted the necessity of actively supporting women's inclusion in Supply Chain (SC) opportunities: "The more skilled women there are, the more quality employees a company has to choose from, and the more entrepreneurs there are to participate in a company's value or supply chain" [1] (p. 15). In a 2018 report, the company [3] notes the importance of empowering women wherever they live, since diversity has a positive relationship with a company's financial outperformance. A report by Deloitte [4] focuses on the talent gap in the Operations field and treats diversity as a way to engage new talents.

In the same line, the World Economic Forum [5] (p. 38) recently stated that "some professions are constrained by the availability of relevant talent, while others could effec- 
tively expand gender parity by embracing greater diversity in hiring and more inclusive managerial practices." Indeed, the SCM function is typically one in which there is a scarcity of talented individuals and a shortage of (wo)manpower (https: / www.elementum.com/ chain-reaction/4-reasons-for-the-supply-chain-talent-shortage (accessed on 17 June 2021)). Gartner's Women in Supply Chain Survey [6] (p. 2) stresses that "Women are underutilized resources in the so-called "war for talent" and that women are not consistently making it through the career pipeline as executive leaders (top managers); women make up 17\% of executives and 39\% of the entire SC workforce. The percentage of women in executive leadership falls to $13 \%$ in the industrial sectors where respondents prefer a Science, Technology, Engineering and Math (STEM) degree for senior hires; these higher education streams are well-known for their lack of gender parity".

Even if we move from an international view to a narrow focus on Western countries (where there are active debates on the place of women in the workplace and society), recent statistics indicate a low presence of women in the SCM function. For example, according to [7], in Germany, women represent $28.2 \%$ of employees in the transport and logistics sector (excluding drivers). Another example comes from Sweden, where, in 2018, women represented $22 \%$ of managers in purchasing, logistics, and transport functions and $15 \%$ of production managers [8].

In the research to date, few studies have looked at the topic of gender diversity in the field of SCM (e.g., [9-11]). It has been studied in other management fields, such as corporate social responsibility (e.g., [12-14]), corporate governance (e.g., [15-17]), and human resources management (e.g., [18,19]). Moreover, SCM is a global function [20], and no study has been conducted on the impact of expatriation on the career path. The authors of [21] (p. 85) call for more research in the SCM research field: "we encourage scholars to take up this call to action to address the critical gap in talent and particularly among underrepresented populations, such as women and minorities." According to a 2019 World Bank report, women represent no less than $49.584 \%$ of the global population and yet are often treated as minorities in social inclusion programs (https:/ / www.worldbank.org/en/ topic/social-inclusion (accessed on 17 June 2021)). This research aims to illustrate the issue of the "glass ceiling" in SCM by studying the career paths of ISLI (Institut Supérieur de Logistique Industrielle) Master of Science graduates and statistically proving the impact of gender and expatriation choice on hierarchical progression.

We begin by reviewing Social Cognitive Career Theory (SCCT) and Social Role Theory (SRT) and the few academic articles linked to our research objective. We examined the profiles of ISLI Specialized Master's graduates (KEDGE Business School, France) from the class of 2000 to the class of 2017 to study their career progression and build a database. This database is tested on IBM SPSS and the hypotheses derived from our conceptual model. It is interesting to look at the profiles of ISLI program graduates because it is recognized as one of the best SCM Master's programs worldwide (https: / www.best-masters.com/ ranking-master-supply-chain-and-logistics.html (accessed on 17 June 2021)); it currently recruits nearly 200 students each year, and, having been founded in 1984, is considered a pioneer in the field.

The primary contributions of this research are twofold. First, this article contributes to addressing gender diversity issues in the SCM field. Closing the gender gap is a crucial element of the United Nations Sustainable Development Goals (SDG). SDG no. 5, "Achieve gender equality and empower all women and girls", (https:/ / www.un.org/ sustainabledevelopment/gender-equality / (accessed on 17 June 2021)) stresses the need for women's full and equal participation in decision-making. However, from an SC perspective, this goal has only been met to a limited extent. Second, the combination of SCCT and SRT in this research attests to their relevance in explaining the relative impact of gender and expatriation choices on graduates' career paths in SCM functions, which are generally seen as masculine. Consequently, this study provides a perspective seldom highlighted in the current literature on SCM, gender diversity, and career progress. 
The paper is structured as follows. In the next section, we present the framework drawn from SCCT and SRT and review the relevant academic literature on gender diversity in the SCM field and on expatriation choices. This section allows us to build the research model and state our hypotheses. Following this, the methodology is described in detail. Next, the main findings are depicted. Finally, we discuss the results, conclude, and present research perspectives.

\section{Theoretical Background}

\subsection{Social Cognitive Career Theory and Social Role Theory}

SCCT [22] is based on the general social cognitive theory [23]. SCCT highlights a set of three personal cognitive factors that affect vocational outcomes: (1) self-efficacy (the extent of a person's belief that they can successfully plan and execute performance depending on the task [24]), (2) outcome expectations (the consequences that people anticipate experiencing when they perform in a given domain [25]), and (3) personal goals which are behavioral intentions to act in ways that elicit desired outcomes [26]. These can be divided into two categories: choice goals (career selection) and performance goals (as individual objectives). The most recent goals affect the way people manage their careers [22,27]. Additionally, SCCT integrates environmental and individual variables that shape the three personal cognitive factors and may explain people's behavior when making career choices [27]. More precisely, the SCCT offers several models, including the SCCT-CSM model. In this model, a large set of antecedents shapes self-efficacy and outcome expectations, such as personal inputs like gender [28] or any other background contextual affordances (such as discrimination in hiring or the glass ceiling [29]). Thus, personal inputs (e.g., work-family aspects, Refs. [30,31]) and background affordances influence the way people manage their careers [27]. Additionally, Ref. [32] (p. 44) point out that "gender and gender-based social roles are the personal inputs that have garnered the most research attention to date." One of those social roles is related to the traditional role of women in the family [33]. However, to our knowledge, this theoretical perspective has never before been mobilized in SCM research, even in the rare cases of research on gender diversity in SCM.

According to [29], SCCT treats gender from a social constructivist position. This means that gender is not simply an inherited biological property but also a social construction [34]. This point is strengthened in [29] (p. 268): "we believe [its] relevance to career development stems largely from the reactions they evoke from the social-cultural environment and from their relation to the structure of opportunity within which career behavior transpires." Consequently, the SCCT encourages a consideration of how the combination of gender, context, and cognitive processes contribute to both talent development and shaping career management [24]. Expatriation can be treated as a "context" given that (1) SCM is a globalized activity, and (2) expatriation may change how a recruiter looks at an applicant's résumé (many professional websites highlight this idea, including: https: / /www. expatnetwork.com/5-reasons-why-working-abroad-is-the-ultimate-cv-booster/ (accessed on 17 June 2021)). On this approach, the earliest research studies aiming to extend social cognitive theory to career behavior show that because of the education they receive, young girls lack opportunities to observe and practice certain activities [35]. Their self-efficacy is more likely to develop to favor so-called "feminine" activities [23]. These findings suggest that these self-limiting effects can restrict women's career paths. This also means that socially constructed external barriers may be internalized and become biased self-efficacy beliefs [29], especially in STEM-related fields [36] such as SCM.

Given that the SCCT encourages looking at the joint contributions of gender, context, and cognitive processes, SRT clearly complements the contributions of the SCCT. SRT was formulated [37] to explain the behavior of women and men as well as the stereotypes (which are consensual beliefs [38] that change over time [39]), attitudes, and ideologies that are relevant to gender. Nowadays, SRT is seen as a significant gender theory [40,41]. According to SRT, gender stereotypes greatly influence daily and professional life, including in the 
SCM function [42]. More precisely, Ref. [43] point out the gender stereotype that women are not suited to leadership roles because of the expectation that they are communal and that leaders are agentic and thus male. The barriers faced by women in masculine environments (and vice versa) are based on such social-role stereotypes. More precisely, the glass-ceiling phenomenon is a set of artificial barriers created by behavioral or organizational prejudices that prevent qualified individuals from advancing in their organization. This implies that women subject to this phenomenon are also subject to discriminatory behaviors [30,31,44]. Finally, gender stereotypes are background affordances according to SCCT [45]. Therefore, the combination of both SCCT and SRT is valuable in analyzing career progression in the SCM function. While the SCCT has not been mobilized in SCM research, a few articles do refer to SRT $[9,10,46]$.

\subsection{Gender Diversity in Supply Chain Management Careers}

There has been a call for additional research [21,47] about the understudied issues of gender diversity in SCM. However, the place of women in this function has been mentioned in the professional and academic literature since the 1990s. Looking at professional magazines, Ref. [11] point out that in publications such as Logistics Management or Motor Transport, women have a low statistical presence (from $5 \%$ to less than $20 \%$ depending on studies) and it is necessary to recruit more women to fill the talent gap [48].

On the research side, the careers of women in SCM have also attracted the attention of some academics. The perceptions of men and women regarding their careers are compared in [47], which introduces important results. First, Ref. [49] shows that women feel like they cannot progress as rapidly as men. Second, this study points out that men's perceptions toward women's career opportunities were less negative, meaning that men were more likely than women to feel that women could advance in an SCM career. Finally, the analysis show that the older the men, the less negative they were in their perceptions of women's career opportunities. This research is the basis for several other studies that extend the results on career-related perspectives of women in SCM. For instance, Refs. [50,51] show that a glass ceiling exists in the SCM function, that there is discrimination against women, and that there was a need for women to be educated in logistics and SCM to empower them and support their successful careers. Another study highlights that in SCM, classical gender inequities can be identified, such as sexual harassment and the trade-off between work and family [52]. Even though women sometimes have to deal with a hostile environment in SCM, Refs. [52,53] found that women embracing such a career are mostly satisfied with their jobs. This is the case even if they are aware of and regret being subjected to a form of discrimination against their gender that slows down their hierarchical progression. Other research studies $[54,55]$ focus on the transportation industry and report the same issues on a larger scale.

Lately, research has focused less on women's careers in SCM, despite studies indicating that it is common for women to make up a small share of those working in the maledominated realm of SCM $[56,57]$. This observation is notably made in an 18-year long-term study entitled Career Patterns of Women in Logistics in the USA $[58,59]$. The study points out that women hold less than $20 \%$ of senior positions in SCM. In a function strongly related to SCM, that of purchasing, a qualitative study by [41] (p. 304) suggests that women's advancement is affected by "inadequate work design, male-dominated cultures, negative stereotypes, high levels of travel and an aggressive ethos." The male domination in the SCM function is one of the major causes of career dissatisfaction for women, who perceive that they may have difficulty overcoming this barrier [60]. The barriers to career progression that were denounced in the research of the 1990s remain [61]. These are, for example, work-life balance, difficulty participating in professional networks, and gender unconscious bias resulting in women asking for career promotion less frequently and men in leadership promoting them less because they perceive a female leader will be preoccupied with her family life. 
Nevertheless, in addition to solving the shortage of talent in SCM, attracting more women and thus having more gender diversity is an excellent way to improve SC performance. For example, compared to men, women SC managers provide new ways to select suppliers based on safety criteria [46], and women are better at spotting contract violations in the field of SC auditing [62]. The need to attract more women in the talent war has been recognized, along with the fact that greater gender diversity will improve operational performance, increase customer value, and foster innovation [61]. A recent study of mixed-gender pairings in the SCM field finds (1) women are more collaborative than men in the roles of both buying and supply agents, (2) both genders are more collaborative when paired with women than when paired with men, and (3) all-women SC pairs outperform all other gender pairings in SC efficiency [10]. This study contributes to the field of SCM research by showing that having more women in the SC function is not only a question of diversity and inclusiveness, or in a more trivial sense of "making room for women in a so-called masculine function", but also a question of SC efficiency. Finally, the authors of a recent study provide food for thought on the contributions of greater gender diversity to the sustainable management of SC [11].

Given the numerous studies highlighting the issue of the SCM glass ceiling, that gender is the main personal input shaping self-efficacy and outcome expectations in SCCT [28], and that a hierarchy is often based on employees (referred to here as "Level 0 ") being managed by middle managers ("Level 1"), who are managed by top managers ("Level 2"), we propose the following hypotheses:

Hypothesis $\mathbf{1}$ (H1): In the SCM function, there is a difference in the number of years spent at each hierarchical level (H1a. Level 0, H1b. Level 1, H1c. Level 2) according to gender.

Hypothesis 2 (H2): In the SCM function, there is a difference in the level of promotion reached according to gender.

\subsection{Expatriation Impact on Careers}

There are very few studies on the linkage between expatriation and career paths [63]. Furthermore, to our knowledge, there is no specific literature associated with expatriation in the field of SCM.

Reviewing the limited relevant studies, we find that [64] shows the impact of expatriation on the career path is very low, which contradicts the usual encouragement in professional environments to expatriate as a career booster. However, self-initiated expatriation is a game-changer in studies on expatriation [65,66]. For [67], self-expatriation is more likely to be initiated by women than by men. At the same time, even if women are willing to expatriate, as soon as they have a family, women are less active in seeking out an international job [68].

Furthermore, Ref. [69] highlight that younger generations are more mobile. They indicate that whatever the generation and the mobility patterns, mobility generates an upward career path. Indeed, mobility builds new skills, and this, in turn, assists in promotion. This trend is even stronger when mobility is external to the company [70]. Consequently, being less mobile has more impact for the younger than for the older generation.

For expatriation to have a positive effect, the expatriate must live in a place and have more than a brief expatriation experience [64]. This requires a particular level of remuneration and acculturation. Moreover, Ref. [71] speaks of a dark side of expatriation. For instance, expatriation to countries under terrorist threats affects job-turnover intentions [72]. Another example is provided by [73], who finds that expatriated females experience more workplace gender harassment than expatriated males. That is particularly the case in countries with institutionalized gender discrimination. The difficulty of achieving worklife balance during expatriation is addressed by $[72,74]$ finds that expatriation reinforces gender stereotypes. 
Indeed, Ref. [75] identifies the different barriers to expatriation for women as the limited female network, family, and work-life balance. Although there is more and more research on female expatriation, this phenomenon is not well understood due to a lack of comparable samples and longitudinal studies [76]. As [77] confirm, most research focuses on Western women who are single or in dual-career relationships in multinational companies. The authors call for new research avenues focused on diversity. For example, in the existing literature, Ref. [78] evoke a second glass ceiling for women in the form of an expatriation glass ceiling. According to [79], women are underrepresented in the international missions, and [80] endorse and underline the responsibility of firms to mentor women for international assignments.

Taking into account that the SCM function is international in nature and considering the studies above, we suggest the following hypotheses:

Hypotheis 3 (H3): In the SCM function, the expatriation choice differs according to gender.

Hypothesis 4 (H4): In the SCM function, there is a difference in the number of years spent at each hierarchical level (H4a. Level 0, H4b. Level 1, H4c. Level 2) depending on the expatriation choice.

Hypothesis 5 (H5): In the SCM function, there is a difference in the level of promotion reached according to the choice of expatriation.

The aforementioned hypotheses lead to the following theoretical model.

\section{Research Objectives and Method}

This research aims to illustrate the glass ceiling issue in SCM by studying the career paths of ISLI Master of Science graduates from KEDGE Business School (France) and statistically prove the impact of gender on hierarchical progression. For this, we carried out a quantitative study based on a dataset of graduates from 2000 to 2017. Classes before 2000 were not considered because the data in the information systems were known to be incomplete and quite inaccurate. Classes after 2017 were not considered either because, compared to 2021, the graduates' professional careers have been too short to be analyzed. Analyzing the careers of ISLI graduates is relevant for several reasons: (1) this Master of Science in SCM, established in 1984, is the oldest in the world; (2) the number of graduates since its creation now number about 4000 SCM professionals; (3) it holds the fifth position in the 2019 Best Masters and MBA Ranking Worldwide in Global Supply Chain Management; and (4) its quality is recognized in the form of many international educational accreditations from the AACSB, EQUIS, AMBA, and CIPS, which specialize in SCM.

This dataset was built first upon the identity of graduates (name + surname + class year + gender) provided from the internal information systems of KEDGE Business School. We then researched each graduate on LinkedIn (as in [81,82]), scanning each of their profiles one by one to complete the dataset. ISLI Master's students have been following LinkedIn training for a few years. From this, we were able to determine if the person had already experienced a professional expatriation in their career, what level of promotion was reached (beginning with none $=0$, first management level $=1$, and second management level $=2$ ), and how many years they spent at each promotion level.

This database was tested using IBM Statistics SPSS v.27 and the hypotheses derived from our conceptual model (Figure 1). It contains a sample of 1081 completed graduate profiles from a population of 1382 ; the sample represents $78.22 \%$ of the entire population of graduates from 2000 to 2017.

Depending on the nature of each of the variables (categorical or continuous), we have selected the relevant statistical tests required to test our hypotheses. Chi-square tests were mobilized because they are relevant to test hypotheses about categorical data [83,84]. MannWhitney $U$ tests, as non-parametric tests, were also used to look for differences between two independent samples (e.g., men/women and choice of expatriation yes/no) $[85,86]$. 
The latter choice was motivated by the results of the Shapiro-Wilk test, which evaluates the distribution normality [87].

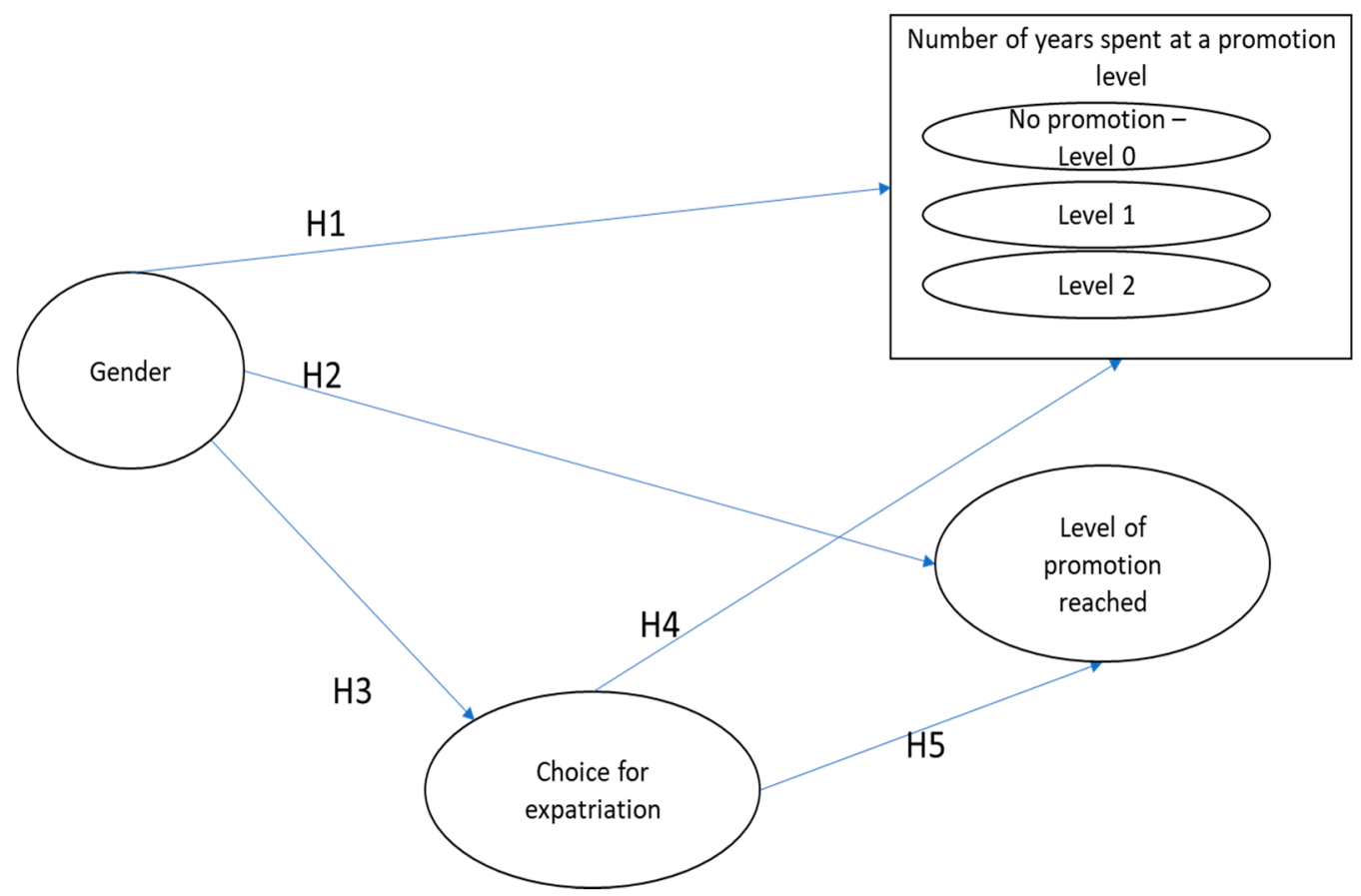

Figure 1. Conceptual model.

\section{Results}

\subsection{Sample Description}

Of the 1081 completed profiles, $33.5 \%$ are women, and $65.5 \%$ are men, which is aligned with the few existing figures about the gender division in the SCM function (Table 1). The descriptive statistics (Table 2) also show the number of completed profiles for each graduation year.

Table 1. Gender division.

\begin{tabular}{ccc}
\hline Gender $\mathbf{1}$ & Number & \% \\
\hline Women & 362 & 33.5 \\
Men & 719 & 66.5 \\
Total & 1081 & 100.0 \\
\hline
\end{tabular}

Table 2. Graduation per year.

\begin{tabular}{cccc}
\hline Graduation Year & Number & $\mathbf{\%}$ & Cumulative $\%$ \\
\hline 2000 & 36 & 3.3 & 3.3 \\
2001 & 45 & 4.2 & 7.5 \\
2002 & 37 & 3.4 & 10.9 \\
2003 & 54 & 5.0 & 15.9 \\
2004 & 53 & 4.9 & 20.8 \\
2005 & 67 & 6.2 & 27.0 \\
2006 & 63 & 5.8 & 32.8 \\
2007 & 37 & 3.4 & 36.2 \\
2008 & 57 & 5.4 & 41.6 \\
2009 & 37 & 3.4 & 45.0 \\
\hline
\end{tabular}


Table 2. Cont.

\begin{tabular}{cccc}
\hline Graduation Year & Number & \% & Cumulative \% \\
\hline 2010 & 49 & 4.5 & 49.5 \\
2011 & 56 & 5.2 & 54.7 \\
2012 & 42 & 3.9 & 58.6 \\
2013 & 60 & 5.5 & 64.1 \\
2014 & 78 & 7.2 & 71.3 \\
2015 & 108 & 10.0 & 81.3 \\
2016 & 42 & 3.9 & 85.2 \\
2017 & 160 & 14.8 & 100.0 \\
Total & 1081 & 100.0 & \\
\hline
\end{tabular}

At this stage of the study, it was informative to run a chi-square test $[83,84]$ to see if the gender distribution was impacted by the year of graduation; some of the reports mentioned above highlight that there is an increasing number of women entering SCM roles. The results are the following: $\chi^{2}(17)=23.825, p>0.05$ (non-significant, more precisely $p=0.124$ ). This means that there is no significant difference in the gender distribution between years of graduation. Looking at the gender distribution of our sample, we conclude that, by the year 2000, the ISLI Master of Science was already quite feminized in comparison with the feminization rate in the SCM function.

\subsection{Gender Influence on Careers}

The literature review shows that gender is often seen as a variable that influences factors relevant to career progression, such as choice of expatriation, the hierarchical level reached, and the number of years spent at each level. To verify if these impacts exist, we ran various tests, depending on the nature of the variables.

First, we ran several Mann-Whitney $U$ tests (Table 3). T-test analyses were not used $[85,86]$ for assessing the potential link between gender and the number of years spent at a hierarchical level as our data do not follow a normal distribution. To check data normality, we ran the Shapiro-Wilk test [87] for each of the three variables: hierarchical Level 0, Level 1, and Level 2. That test proved that none followed a normal distribution. In this case, the Mann-Whitney $U$ test is preferred since it is not sensitive to normal distribution [88]. Mann-Whitney $U$ tests are widely used non-parametric techniques for testing two different samples from the same population [89]. Such tests do not show how the groups differ, only that they do, in some way.

Table 3. Influence of gender on the number of years spent at each hierarchical level. (Significative tests are in bold).

\begin{tabular}{ccccc}
\hline Independent Variable & Dependent Variables & U Mann-Whitney & Sig. & Status \\
\hline \multirow{3}{*}{ Gender } & Level 0 & $102,846.5$ & $\mathbf{0 . 0 0 0}$ & H1a validated \\
\cline { 2 - 5 } & Level 1 & $106,539.5$ & $\mathbf{0 . 0 0 0}$ & H1b validated \\
\cline { 2 - 5 } & Level 2 & $112,169.0$ & $\mathbf{0 . 0 0 0}$ & H1c validated \\
\hline
\end{tabular}

Looking at descriptive statistics, we find out that women spend on average 7.33 years at Level 0 when men spend 5.74 years. At Level 1, women spend 2.74 years on average when men spend 4.08 years on average. Finally, at Level 2, women spend 0.56 years compared to men who spend 1.58 years. These statistics suggest that women spend more time at Level 0 than men before being promoted. In contrast, the average length of time spent at higher levels falls since many women have not had the opportunity to move up the ladder and therefore accumulate zero years at these levels. This is why it is interesting to know if gender has an impact on the hierarchical level reached.

Second, we ran a chi-square test to determine if gender impacts the hierarchical level reached in the SCM function. The results are: $\chi^{2}(2)=39.660, p<0.05$ (significant, $p=0.000$ ). 
Thus, H2 was validated. Furthermore, these results can be analyzed using descriptive statistics. These show the gender distribution on each of the three hierarchical levels. The results in Table 4 show that the proportion of women decreases the higher the hierarchical level.

Table 4. Gender repartition at each hierarchical level.

\begin{tabular}{|c|c|c|c|c|c|}
\hline & & & Women & Men & Total \\
\hline \multirow{6}{*}{$\begin{array}{l}\text { Hierarchical } \\
\text { level reached }\end{array}$} & \multirow{2}{*}{ Level 0} & Number & 196 & 264 & 460 \\
\hline & & $\%$ & $42.6 \%$ & $57.4 \%$ & $100.0 \%$ \\
\hline & \multirow{2}{*}{ Level 1} & Number & 126 & 280 & 406 \\
\hline & & $\%$ & $31.0 \%$ & $69.0 \%$ & $100.0 \%$ \\
\hline & \multirow{2}{*}{ Level 2} & Number & 40 & 175 & 215 \\
\hline & & $\%$ & $18.6 \%$ & $81.4 \%$ & $100.0 \%$ \\
\hline \multirow{2}{*}{\multicolumn{2}{|c|}{ Total }} & Number & 362 & 719 & 1081 \\
\hline & & $\%$ & $33.5 \%$ & $66.5 \%$ & $100.0 \%$ \\
\hline
\end{tabular}

Third, another chi-square test was run to find out whether gender influences the choice of expatriation. The result is: $\chi^{2}(1)=0.045, p>0.05$ (non-significant, $p=0.832$ ). Thus, H3 was rejected.

\subsection{Expatriation Influence on Careers}

Another idea emerging from the literature review is that expatriation can have an impact on career progression. Therefore, we used the U Mann-Whitney test to see the impact of the expatriation choice on the number of years spent at each of the three hierarchical levels. Table 5 shows that such a choice has an impact at Levels 1 and 2 (with managerial duties), so there is a link between the choice of expatriation and the time spent at each hierarchical level.

Table 5. Influence of choice of expatriation on number of years spent at each level. (Significative tests are in bold).

\begin{tabular}{ccccc}
\hline Independent Variable & Dependent Variables & U Mann-Whitney & Sig. & Status \\
\hline \multirow{3}{*}{ Expatriation } & Level 0 & $121,104.0$ & $\mathbf{0 . 2 1 9}$ & H4a rejected \\
\cline { 2 - 5 } & Level 1 & $111,759.5$ & $\mathbf{0 . 0 0 1}$ & H4b validated \\
\cline { 2 - 5 } & Level 2 & $118,235.5$ & $\mathbf{0 . 0 0 9}$ & H4c validated \\
\hline
\end{tabular}

Looking at descriptive statistics where the choice of expatriation has a significant effect on the hierarchical level reached, graduates who have worked abroad spent 4.23 years at Level 1 compared to 3.35 years by those who did not work abroad and who may have spent much less time at that level. In the same way, at Level 2, graduates who worked abroad spent 1.5 years at that level compared to 1.11 for the others. These descriptive statistics suggest that those who dared to go abroad for work may have greater career opportunities and reach a higher level in the hierarchy. For this reason, it is interesting to know if expatriation choice has an impact on the hierarchical level reached (H5).

Indeed, we ran another chi-square test to find out whether the choice of expatriation has an influence on the hierarchical level reached. The result is $\chi^{2}(2)=9.804, p<0.05$ (significant, $p=0.007$ ), which enables us to validate $\mathrm{H} 5$. These results can be commented on using descriptive statistics on the impact of the choice of expatriation distribution on each of the three hierarchical levels. The results in Table 6 show that the higher in the hierarchy, the more SC managers have been expatriated. This result was not obvious from the literature review. The results of [64] are therefore contradicted. The self-expatriation trend described as a game-changer by $[65,66]$ may explain this difference. 
Table 6. Choice of expatriation repartition at each hierarchical level.

\begin{tabular}{|c|c|c|c|c|c|}
\hline & & & No Expatriation & Expatriation & Total \\
\hline \multirow{6}{*}{$\begin{array}{l}\text { Hierarchical Level } \\
\text { Reached }\end{array}$} & \multirow{2}{*}{ Level 0} & Number & 333 & 127 & 460 \\
\hline & & $\%$ & $72.4 \%$ & $27.6 \%$ & $100.0 \%$ \\
\hline & \multirow{2}{*}{ Level 1} & Number & 273 & 133 & 406 \\
\hline & & $\%$ & $67.2 \%$ & $32.8 \%$ & $100.0 \%$ \\
\hline & \multirow{2}{*}{ Level 2} & Number & 130 & 85 & 215 \\
\hline & & $\%$ & $60.5 \%$ & $39.5 \%$ & $100.0 \%$ \\
\hline \multirow{2}{*}{\multicolumn{2}{|c|}{ Total }} & Number & 736 & 345 & 1081 \\
\hline & & $\%$ & $68.1 \%$ & $31.9 \%$ & $100.0 \%$ \\
\hline
\end{tabular}

Does Gender or Expatriation Choice Have the Greatest Influence on Careers?

Since H3 was rejected (gender has no significant impact on the choice of expatriation), this means that there is no possibility of mediation [89] by the expatriation choice variable on the relationship between gender and time at each of the levels or the level reached by graduates. Furthermore, since gender and expatriation have a significant impact on both the time spent at each level of the hierarchy and the level of hierarchy reached, it is interesting to consider which of the two variables has the greatest impact on the careers of graduates.

To do this, we first selected the graduates who have reached Level 2 in the hierarchy. Indeed, since they have spent time at each of the hierarchical levels, it is possible to use a two-way ANOVA analysis to find which of the two variables has the greatest impact on the time spent at each level. This statistical test is suitable because the data follows a normal distribution for the sample of graduates who reached Level 2. Insofar as the H4a hypothesis is rejected (Level $0=$ no promotion), the comparison between the impact of the gender and expatriation choice variables was limited to the number of years spent at Levels 1 and 2 (H1b, H1c, H4b, and H4c are validated).

The subsample for the two-way ANOVA was composed of 188 observations and does not include graduates who started their own business and thus moved from Level 0 to Level 2 directly. In this subsample, there were 33 women and 153 men, 107 of whom have never been expatriated and 79 who have already made this choice in their career.

As expected, the results (Table 7) show that initially there is no interaction between gender and expatriation choice (see H3): at Level 1, Gender * Expatriation $\mathrm{F}(1.96)=0.685$, $p=0.409$ (non-significant) and at Level 2 Gender * Expatriation $\mathrm{F}(1.96)=0.483, p=0.488$ (non-significant). Therefore, we focus separately and more precisely on the variables of gender and choice of expatriation. Regarding the choice of expatriation, the results show that for this subsample who have reached Level 2, this variable has no impact on the time spent at Level $1(\mathrm{~F}(1.96)=0.773, p=0.380$ non-significant $)$ or Level $2(\mathrm{~F}(1.96)=0.028$, $p=0.867$ non-significant). On the contrary, gender has an impact on the number of years spent at Level $2(\mathrm{~F}(1.96)=4.856, p=0.029$ significant $p<0.05)$ but not on the number of years spent at Level $1(\mathrm{~F}(1.96)=0.036, p=0.850$ non-significant).

Descriptive statistics show that for this subsample, women averaged 4.82 years at Level 2 compared with 6.32 years for men, while for Level 1, women and men averaged just over 6 years (women $=6.21$ years, men $=6.52$ years). These results mean that, on average, women lost more time at the beginning of their careers to move from Level 0 to Level 1, which implies less cumulative time spent at Level 2 than men. The descriptive statistics show that women from this subsample spent 4.88 years at Level 0 on average compared to men with an average of 3.68 years. This means that even the (few) women who have managed to reach the highest levels of management in the SCM hierarchy, they have benefited from having a slower career progression at the beginning of their careers than men. 
Table 7. Two-way ANOVA comparison between the impact of gender and expatriation on the number of years spent at Levels 1 and 2. (Significative tests are in bold).

\begin{tabular}{clcc}
\hline & Variables & F & Sig. \\
\hline \multirow{2}{*}{ Gender } & Level 1 (nb. years spent) & 0.036 & 0.850 \\
& Level 2 (nb. years spent) & 4.856 & $\mathbf{0 . 0 2 9}$ \\
\hline \multirow{2}{*}{ Expatriation } & Level 1 (nb. years spent) & 0.773 & 0.380 \\
& Level 2 (nb. years spent) & 0.028 & 0.867 \\
\hline \multirow{2}{*}{ Gender* Expatriation } & Level 1 (nb. years spent) & 0.685 & 0.409 \\
& Level 2 (nb. years spent) & 0.483 & 0.488 \\
\hline
\end{tabular}

Table Footer: * means interaction.

Then, we analyzed the difference in influence between the gender and expatriation variables on the level of promotion achieved. To do so, we compared the chi-square results already calculated previously ( $\mathrm{H} 2$ and $\mathrm{H} 5)$. The values shown in Table 8 indicate that gender has an impact 4.05 times higher than the choice of expatriation on the level of promotion achieved. This means that a woman who wishes to move up the SCM function hierarchy can hardly rely on a professional expatriation to compensate for her gender. That confirms the results of [78] that there is an expatriation-related glass ceiling.

Table 8. Chi-square comparison between the impact of gender and expatriation on the hierarchical level reached. (Significative tests are in bold).

\begin{tabular}{cccc}
\hline Hypotheses & Value & df & $p$-Value \\
\hline H2: Gender $\rightarrow$ Hierarchical level & 39.660 & 2 & $\mathbf{0 . 0 0 0}$ \\
H5: Expatriation $\rightarrow$ Hierarchical level & 9.804 & 2 & $\mathbf{0 . 0 0 7}$ \\
\hline
\end{tabular}

\section{Discussion and Conclusions}

This research tests a framework that examines career paths, gender, and expatriation choice in the SCM function with several insights for theory and practice. We addressed the gender-diversity gaps in the SCM field by illustrating the glass ceiling for women in SCM. We studied the career paths of ISLI Master of Science graduates and statistically proved the impact of gender and expatriation choice on hierarchical progression. Our sample confirms the gender divide in SCM (women make up about $33 \%$ and men about $66 \%$ of the field). In addition, women spend more time at each hierarchical level. The hierarchical level reached is also related to gender. For example, women who reached the highest level took longer than men to do so. Although the literature indicates that expatriation is more complicated for a woman [75], our study does not validate the impact of gender on the choice of an expatriation ( $\mathrm{H} 3$ rejected). There is a link between expatriation and the hierarchical level reached. However, this link is four times weaker than for gender. In the SCM function, for a woman, expatriating will only partially compensate for the fact that she is a woman.

\subsection{Theoretical Implications}

This research answers the call of [21,47] for more knowledge on gender diversity in the SCM function. It contributes to organizational theory by highlighting the applicability of SCCT [22] and SRT [35] to gender diversity and expatriation in the specific field of SCM. In doing so, we specifically provided additional insights on recent studies on gender diversity in SCM [9-11] by using a combination of theoretical lenses showing that personal inputs (such as gender) and background affordances (such as barriers that produce the glassceiling effect [19]) may influence the way women and men advance in their careers [27].

The SCCT was useful in explaining that gender, as an individual variable [28], may impact career paths (in line with [19]). Moreover, our study proves the rising relevance of SRT in the SCM context (such as in $[9,11,46]$ ), more precisely by explaining that gender and associated social role stereotypes lead to a glass ceiling for women. The combination of 
these theories provides an integrative perspective of how gender impacts the career paths in SCM by acknowledging that gender stereotypes from SRT are background affordances according to SCCT [44]. Thus, this research also brings a new theoretical clarification to the pervasive glass ceiling faced by women in SCM and already pointed out in previous studies from the 1990s [50,51].

Another theoretical contribution concerns the impact of expatriation choice on career paths. Indeed, this study complements the few studies on those links [63], more precisely by providing some perspectives from the global SCM function. Here also, SCCT provides a useful explanation that expatriation may be considered a "context" that may shape career management [24]. Finally, this study was an opportunity to advance the understanding of how gender influences career paths in SCM and determine if expatriation choice impacts that path. No existing research has been found on expatriation or mobility in SCM. Our study presents some initial results, but it is important to deepen and further the knowledge in this field.

\subsection{Implications for Practitioners}

The findings of this study have implications for SC practitioners. The results show that, from the beginning, there is a bias impacting the chances that women will follow similar career paths to men. Indeed, from the very beginning of education in SCM, women are less numerous than men. It is, therefore, necessary for the entire SCM sector to take ownership of the issue and promote and encourage access to these programs for young girls. In this context, the SC actors must be involved in this promotion by, for example, intervening in higher education and participating in job forums organized from middle school onwards. Indeed, the literature review shows that women evolve in a very masculine context, which leads to biases in their career development. An increase in the number of women in the profession would make it possible to change this environment and break this first glass ceiling. Breaking it is of utmost importance in filling the talent gap in SCM [4-6,48]. Employers must pay particular attention to the gender mix of their employees in the SC sector and be proactive.

A second important output is the time spent by women at each hierarchical level. The reasons may vary according to each situation (e.g., the traditional role of women in their family environment [31]; work-life balance [75]; sexual harassment and gender discrimination [52]). However, paying attention to this fact for internal promotion seems crucial. Employers can set up support for women such as a crèche, no meetings after 6 p.m., or any other device allowing the balance of family tasks between men and women. Beyond these actions, employers must also provide an inclusive environment that leaves no room for discrimination of any kind.

Third, this research may empower women as SC practitioners by offering them clear statistics about the inequalities that remain in SCM career development between women and men and showing them that even the choice of expatriation would not fully compensate for the fact that they are female. These compelling arguments can serve as a basis for discussion with an employer in career advancement negotiations.

Finally, our research tends to nuance, for the SCM function, the usual discourse of the business world, which aims to promote expatriation as a career booster. By contrast, our results show that at the beginning of one's career, the impact of expatriation is not significant.

\subsection{Limitations and Further Research Directions}

As with any research, our study is subject to several limitations that offer an opportunity for further research. First, our study looks exclusively at the ISLI Master of Sciences graduates from KEDGE Business School (France) from the class of 2000 to the class of 2017. Future studies in other countries, other business schools, and other engineering schools offering this specialization might provide comparative data. 
Additionally, we collected data on a limited number of variables (i.e., gender, expatriation choice, hierarchical level, and the number of years spent at each level). We believe that further research would benefit from integrating other variables such as education prior to enrolling in ISLI (STEM or business background) or other variables related to the SCCT such as personal goals or beliefs. For instance, a particularly relevant factor from SCCT is the "masculinity" personal trait. This refers to an instrumental result- and problem-solving orientation that is stereotypically seen as masculine [90-92] as per SRT [93]. Comparisons between the results for the SCM function and other functions would also enrich the debate on the glass ceiling, the impact of gender on career progression, and the possible choice of expatriation.

Another limitation of this study is the use of LinkedIn to collect some data. As have other researchers [83], we used LinkedIn to identify the current position of those in our sample. However, Ref. [83] state that using professional social networks may produce validity issues since some people embellish their job titles or may not update their profiles. A third limit arises from the second. In collecting data via a professional social network, we were limited in our ability to obtain data on "personal inputs" (other than gender) that, in terms of SCCT $[27,28,30]$, could influence careers. However, other variables such as human capital (e.g., experience, career interruptions, education level, training, and development), individual traits (e.g., masculinity/instrumentality, ambition, self-confidence, leadership motivation), or environmental structural factors (e.g., male hierarchy, homophily, internal labor markets) and interpersonal elements (e.g., home status, mentor support, educational encouragement) may also influence career paths [41,94-96].

Consequently, one research avenue could be to collect data directly from the graduates in a research survey that includes further variables from SCCT and SRT. This would allow a more comprehensive conceptual model to be analyzed through Structural Equation Modeling as in [94]. This data collection would no doubt be valuable but would also be challenging to conduct.

Author Contributions: Conceptualization, S.R. and A.J.; methodology, S.R. and A.J.; software, S.R. and A.J.; validation, S.R. and A.J.; formal analysis, S.R.; investigation, S.R. and A.J.; data curation, S.R.; writing—original draft preparation, S.R. and A.J.; writing—review and editing, S.R. and A.J.; visualization, S.R.; supervision, S.R. and A.J.; project administration, S.R. and A.J. All authors have read and agreed to the published version of the manuscript.

Funding: This research received no external funding.

Acknowledgments: The authors want to thank Marie-Laure Furgala and Emmanuelle Barthet for all their help in collecting the data.

Conflicts of Interest: The authors declare no conflict of interest.

\section{References}

1. McKinsey \& Company. Women Matter: Women at the Top of Corporations: Making It Happen; McKinsey \& Company: Paris, France, 2010.

2. World Economic Forum. Global Value Chain Policy Series Gender. 2018. Available online: https://www.wita.org/nextgentrade/ global-value-chain-policy-series-gender/ (accessed on 15 June 2021).

3. McKinsey \& Company. Delivering through Diversity; McKinsey \& Company: Paris, France, 2018. Available online: http: / / sylviakern.com/wp-content/uploads/2019/10/Delivering-through-diversity_full-report_KcKinsey_2018_BusinessCase_ DIM2018-2.pdf (accessed on 15 June 2021).

4. Deloitte. Women in the Boardroom. A Global Perspective. 2015. Available online: https:/ /www2.deloitte.com/content/dam/ Deloitte/global/Documents/Risk/gx-ccg-women-in-the-boardroom-a-global-perspective4.pdf (accessed on 15 June 2021).

5. World Economic Forum. Global Gender Gap Report. 2020. Available online: https://www.weforum.org/reports/gender-gap-20 20-report-100-years-pay-equality (accessed on 15 June 2021).

6. Gartner. Women in Supply Chain Survey Highlights Consumer Value Chain Progress. 2020. Available online: https://www. gartner.com/en/supply-chain/trends/2020-women-in-supply-chain-survey-highlights (accessed on 15 June 2021).

7. Destatis. Statistisches Jahrbuch Deutschland und Internationales. Germany. 2019. Available online: https://www.destatis.de/ DE/Themen/Querschnitt/Jahrbuch/statistisches-jahrbuch-2019-dl.pdf?_blob=publicationFile (accessed on 15 June 2021). 
8. Statistics Sweden. The Swedish Occupational Register with Statistics 2018. In Statistical Messages AM 33 SM 2001 ; Sweden, 2018. Available online: https:/ / www.scb.se/publication/39648 (accessed on 15 June 2021).

9. Chin, T.A.; Tat, H.H. Does Gender Diversity Moderate the Relationship Between Supply Chain Management Practice and Performance in the Electronic Manufacturing Services Industry? Int. J. Logist. Res. Appl. 2015, 18, 35-45. [CrossRef]

10. Ma, S.; Hao, L.; Aloysius, J.A. Women Are an Advantage in Supply Chain Collaboration and Efficiency. Prod. Oper. Manag. 2020. [CrossRef]

11. Ruel, S.; Fritz, M.; Subramanian, N. Gender Diversity for Sustainability Management: Developing a Research Agenda from a Supply Chain Perspective. Logistique Manag. 2020, 28, 224-239. [CrossRef]

12. Rao, K.; Tilt, C. Board composition and corporate social responsibility: The Role of Diversity, Gender, Strategy and Decision Making. J. Bus. Ethics 2016, 138, 327-347. [CrossRef]

13. Galbreath, J. Is Board Gender Diversity Linked to Financial Performance? The Mediating Mechanism of CSR. Bus Soc. 2018, 57, 863-889. [CrossRef]

14. Yarram, S.R.; Adapa, S. Board Gender Diversity and Corporate Social Responsibility: Is There a Case for Critical Mass? J. Clean Prod. 2020, 278, 123319. [CrossRef]

15. Francoeur, C.; Labelle, R.; Sinclair-Desgagné, B. Gender Diversity in Corporate Governance and Top Management. J. Bus. Ethics 2008, 81, 83-95. [CrossRef]

16. Báez, A.B.; Báez-García, A.J.; Flores-Muñoz, F.; Gutiérrez-Barroso, J. Gender Diversity, Corporate Governance and Firm Behavior: The Challenge of Emotional Management. Eur. Res. Manag. Bus. Econ. 2018, 24, 121-129. [CrossRef]

17. Orazalin, N. Board Gender Diversity, Corporate Governance, and Earnings Management. Gend. Manag. 2019, 35, 37-60. [CrossRef]

18. Ferris, G.R.; Frink, D.D.; Galang, M.C. Diversity in the Workplace: The Human Resources Management Challenges. Hum. Resour Plan. 1993, 16, 41-51.

19. Ali, M. Impact of Gender-Focused Human Resource Management on Performance: The Mediating Effects of Gender Diversity. Aust. J. Manag. 2016, 41, 376-397. [CrossRef]

20. Houlihan, J.B. International Supply Chain Management. Int. J. Phys. Distrib. Logis. Manag. 1985, 15, $22-38$.

21. Zinn, W.; Goldsby, T.J.; Cooper, M.C. Researching the Opportunities and Challenges for Women in Supply Chain. J. Bus. Logist. 2018, 39, 84-86. [CrossRef]

22. Lent, R.W.; Brown, S.D.; Hackett, G. Toward a Unifying Social Cognitive Theory of Career and Academic Interest, Choice, and Performance. J. Vocat. Behav. 1994, 45, 79-122. [CrossRef]

23. Bandura, A. Social Foundations of Thought and Action; Prentice Hall: Englewood Cliff, NJ, USA, 1986.

24. Bandura, A. Self-Efficacy: The Exercise of Control; Freeman: New York, NY, USA, 1997.

25. Lent, R.W. Social Cognitive Career Theory. In Career Development and Counseling: Putting Theory and Research to Work, 2nd ed.; Brown, S.D., Lent, R.W., Eds.; Wiley: Hoboken, NJ, USA, 2013; pp. 115-146.

26. Gollwitzer, P.M. Implementation intentions: Strong effects of simple plans. Am. Psychol. 1999, 54, 493-503. [CrossRef]

27. Lent, R.W.; Brown, S.D. Social Cognitive Model of Career Self-Management: Toward a Unifying View of Adaptive Career Behavior Across the Life Span. J. Couns. Psychol. 2013, 60, 557-568. [CrossRef] [PubMed]

28. Tokar, D.M.; Thompson, M.N.; Plaufcan, M.R.; Williams, C.M. Precursors of Learning Experiences in Social Cognitive Career Theory. J. Vocat. Behav. 2007, 71, 319-339. [CrossRef]

29. Lent, R.W.; Brown, S.D.; Hackett, G. Social cognitive career theory. In Career Choice and Development, 4th ed.; Brown, S.D., Ed.; Jossey-Bass: San Francisco, CA, USA, 2002; pp. 255-311.

30. Morrison, A.M.; von Glinow, M.A. Women and Minorities in Management. Am. Psychol. 1990, 45, $200-208$.

31. Schneer, J.A.; Reitman, F. The Impact of Gender as Managerial Careers Unfold. J. Vocat. Behav. 1995, 47, 290-315. [CrossRef]

32. Thompson, M.N.; Dahling, J.J.; Chin, M.Y.; Melloy, R.C. Integrating Job Loss, Unemployment, and Reemployment with Social Cognitive Career Theory. J. Career Assess. 2017, 25, 40-57. [CrossRef]

33. Ferry, T.R.; Fouad, N.A.; Smith, P.L. The Role of Family Context in a Social Cognitive Model for Career-Related Choice Behavior: A Math and Science Perspective. J. Vocat. Behav. 2000, 57, 348-364. [CrossRef]

34. Fassinger, R.E. Gender and Sexuality in Human Development: Implications for Prevention and Advocacy in Counseling Psychology. In Handbook of Counseling Psychology, 3rd ed.; Brown, S.D., Lent, R.W., Eds.; Wiley: New York, NY, USA, 2000; pp. 346-378.

35. Hackett, G.; Betz, N.E. A Self-Efficacy Approach to the Career Development Of Women. J. Vocat. Behav. 1981, 18, 326-339. [CrossRef]

36. Lapan, R.T.; Boggs, K.R.; Morrill, W.H. Self-Efficacy as a Mediator of Investigative and Realistic General Occupational Themes on the Strong-Campbell Interest Inventory. J. Couns. Psychol. 1989, 36, 176-182. [CrossRef]

37. Eagly, A.H. Sex Differences in Social Behavior: A Social-Role Interpretation; Lawrence Earlbaum Associates: Hillsdale, NJ, USA, 1987.

38. Broverman, I.K.; Vogel, S.R.; Broverman, D.M.; Clarkson, F.E.; Rosenkrantz, P.S. Sex-Role Stereotypes: A Current Appraisal. J. Soc. Issues 1972, 28, 59-78. [CrossRef]

39. Eagly, A.H.; Nater, C.; Miller, D.I.; Kaufmann, M.; Sczesny, S. Gender Stereotypes Have Changed: A Cross-Temporal MetaAnalysis of U.S. Public Opinion Polls from 1946 to 2018. Am. Psychol. 2020, 75, 301-315. [CrossRef] [PubMed] 
40. Eagly, A.H.; Wood, W. Social role theory. In Handbook of Theories in Social Psychology; van Lange, P., Kruglanski, A., Higgins, E.T., Eds.; Sage Publications Ltd: Thousand Oaks, CA, USA, 2012; pp. 458-476.

41. Lawrence, J.; Lonsdale, C.; Le Mesurier, N. Access denied? Exploring the Causes of the Low Representation of Women in Senior Executive Positions Within Procurement. J. Purch. Supply Manag. 2018, 24, 304-313. [CrossRef]

42. Eagly, A.H.; Sczesny, S. Gender Roles in the Future? Theoretical Foundations and Future Research Directions. Front. Psychol 2019, 10, 1-3. [CrossRef] [PubMed]

43. Eagly, A.H.; Karau, S.J. Role Congruity Theory of Prejudice Toward Female Leaders. Psychol. Rev. 2002, 109, 573. [CrossRef] [PubMed]

44. Lyness, K.S.; Thompson, D.E. Above the Glass Ceiling? A Comparison of Matched Samples of Female and Male Executives. J. Appl. Psychol. 1997, 82, 359-375. [CrossRef] [PubMed]

45. Bennett, S.L.R. Contextual Affordances of Rural Appalachian Individuals. J. Career Dev. 2008, 34, $241-262$.

46. Park, D.; Krishnan, H.A. Gender Differences in Supply Chain Management Practices. Int. J. Manag. Enterp. Dev. 2005, 2, 27-37. [CrossRef]

47. Esper, T.L.; Goldsby, T.J.; Zinn, W.A. Challenge in Our Time: Issues of Race in Supply Chain Management. J. Bus. Logist. 2020, 41, 178-181. [CrossRef]

48. Cottrill, K. Are You Prepared for the Supply Chain Talent Crisis; MIT Center for Transportation and Logistics: Cambridge, MA, USA, 2010; pp. 1-11.

49. Andre, R.A. Comparison of Career Status and Attitudes Among Men and Women in Logistics. Logist Transp. Rev. 1995, $31,179$.

50. Lynagh, P.M.; Murphy, P.R.; Poist, R.F. Career-Related Perspectives Regarding Women in Logistics: A Comparative Analysis. Transp. J. 1996, 36, 35-42.

51. Lynagh, P.M.; Murphy, P.R.; Poist, R.F. Career Perspectives of Women in Distribution: Congruency or Contrast? Int. J. Phys. Distrib. Logist. Manag. 1999, 29, 192-207. [CrossRef]

52. Knemeyer, A.M.; Murphy, P.R.; Poist, R.F. Opportunities for Women in Logistics: An Analysis of Student Perspectives. Transp. J. $1999,39,34-41$.

53. Johnson, J.C.; McClure, D.J.; Schneider, K.C. Job Satisfaction of Logistics Managers: Female Versus Male Perspectives. Transp. J. 1999, 39, 5-19.

54. Kau, S.; Kleiner, B.H. New Developments Concerning Discrimination and Sexual Harassment in the Transportation Industry. Int. J. Sociol. Soc. Policy 2001, 21, 165-174. [CrossRef]

55. Simpson, R.; Holley, D. Can Restructuring Fracture The Glass Ceiling? The Case of Women Transport and Logistics Managers. Women Manag. Rev. 2011, 16, 174-182. [CrossRef]

56. Hendricks, K.B.; Hora, M.; Singhal, V.R. An Empirical Investigation on the Appointments of Supply Chain and Operations Management Executives. Manag. Sci. 2015, 61, 1562-1583. [CrossRef]

57. Flöthmann, C.; Hoberg, K. Career Patterns of Supply Chain Executives: An Optimal Matching Analysis. J. Bus. Logist. 2017, 38, 35-54. [CrossRef]

58. Cooper, M.C.; Sanstosa, J.; Hurst, D.C.; Sanders, N.R. 2011 Career Patterns of Women in Logistics: Mentoring and Balancing Work, Life, and Study. Presented at the Council of Supply Chain Management Professionals Annual Conference, Philadelphia, PA, USA, 2-5 October 2011.

59. Cooper, M.C.; Santosa, J.; Hurst, D.C.; Sanders, N.R.; Andic, E.; Polyviou, M. 2012 Career Patterns in Logistics and Supply Chain Management. Presented at the Council of Supply Chain Management Professionals Annual Conference, Atlanta, GA, USA, 30 September-3 October 2012.

60. Goffnett, S.P.; Cook, R.L.; Williams, Z.; Gibson, B.J. Understanding Satisfaction with Supply Chain Management Careers: An Exploratory Study. Int. J. Logist. Manag. 2012, 23, 35-158. [CrossRef]

61. Nix, N.; Stiffler, D. 2016. WOMEN in Supply Chain. Supply Chain Manag. Rev. 2016, 20, 44-51.

62. Short, J.L.; Toffel, M.W.; Hugill, A.R. Monitoring Global Supply Chains. Strateg. Manag. J. 2016, 37, 1878-1897. [CrossRef]

63. Ramaswami, A.; Carter, N.M.; Dreher, G.F. Expatriation and Career Success: A Human Capital Perspective. Hum. Relat. 2016, 69, 1959-1987. [CrossRef]

64. Benson, G.S.; Pattie, M. Is Expatriation Good for my Career? The Impact Of Expatriate Assignments on Perceived and Actual Career Outcomes. Int. J. Hum. Resour. Manag. 2008, 19, 1636-1653. [CrossRef]

65. Baruch, Y.; Altman, Y.; Tung, R.L. Career Mobility in a Global Era: Advances in Managing Expatriation and Repatriation. Acad. Manag. Ann. 2016, 10, 841-889. [CrossRef]

66. Doherty, N. Understanding the Self-initiated Expatriate: A Review and Directions for Future Research. Int. J. Manag. Rev. 2013, 15, 447-469. [CrossRef]

67. Andresen, M.; Biemann, T.; Pattie, M.W. What Makes Them Move Abroad? Reviewing and Exploring Differences Between Self-Initiated and Assigned Expatriation. Int. J. Hum. Resour. Manag. 2015, 26, 932-947. [CrossRef]

68. Tharenou, P. Disruptive Decisions to Leave Home: Gender and Family Differences in Expatriation Choices. Organ. Behav. Hum. Decis. Process. 2008, 105, 183-200. [CrossRef]

69. Lyons, S.T.; Schweitzer, L.; Ng, E.S. How Have Careers Changed? An Investigation of Changing Career Patterns Across Four Generations. J. Manag. Psychol. 2015, 30, 8-21. [CrossRef]

70. Feldman, D.C.; Ng, T.W.H. Careers: Mobility, Embeddedness, and Success. J. Manag. 2007, 33, 350-377. [CrossRef] 
71. Bader, A.K.; Froese, F.J.; Kraeh, A. Clash of Cultures? German Expatriates' Work-Life Boundary Adjustment in South Korea. Eur. Manag. Rev. 2018, 15, 357-374. [CrossRef]

72. Bader, B.; Schuster, T.; Bader, A.K.; Shaffer, M. The Dark Side of Expatriation: Dysfunctional Relationships, Expatriate Crises, Prejudice and a VUCA world. J. Glob. Mobil. 2019, 7, 126-136. [CrossRef]

73. Bader, B.; Stoermer, S.; Bader, A.K.; Schuster, T. Institutional Discrimination Of Women and Workplace Harassment of Female Expatriates: Evidence from 25 Host Countries. J. Glob. Mobil. 2018, 6, 40-58. [CrossRef]

74. Shortland, S. Gender Diversity In Expatriation: Evaluating Theoretical Perspectives. Gend. Manag. 2009, 24, 365-386. [CrossRef]

75. Shortland, S. Female Expatriates' Motivations and Challenges: The Case of Oil and Gas. Gend. Manag. 2018, 33, 50-65. [CrossRef]

76. Shortland, S.; Altman, Y. What Do We Really Know About Corporate Career Women Expatriates? Eur. J. Int. Manag. 2011, 5, 209-234. [CrossRef]

77. Hutchings, K.; Michailova, S. Female Expatriates: Towards a More Inclusive View. In Research Handbook of Expatriates; McNulty, Y., Selmer, J., Eds.; Edward Elgar Publishing: Northampton, MA, USA, 2017; pp. 241-260.

78. Insch, G.S.; McIntyre, N.; Napier, N.K. The Expatriate Glass Ceiling: The Second Layer of Glass. J. Bus. Ethics 2008, 83, 19-28. [CrossRef]

79. Menzies, J. Shattering the Glass Border: The Factors that are Related To Women Participating in International Assignments. Int. J. Bus. Glob. 2012, 8, 349-363. [CrossRef]

80. Domínguez, M.A.; Rivo-López, E.; Villanueva-Villar, M. 'The Glass Ceiling': Myth or Reality? An Expatriation Perspective. Organ Dyn. 2019, 48, 100706. [CrossRef]

81. Li, L.; Zheng, G.; Peltsverger, S.; Zhang, C. Career Trajectory Analysis of Information Technology Alumni: A LinkedIn Perspective. In Proceedings of the 17th Annual Conference on Information Technology Education, Boston, MA, USA, 28 September-1 October 2016; pp. 2-6.

82. Coen, D.; Vannoni, M. Sliding Doors In Brussels: A Career Path Analysis of EU Affairs Managers. Eur. J. Political Res. 2016, 55, 811-826. [CrossRef]

83. McHugh, M.L. The Chi-Square Test of Independence. Biochem. Med. 2013, 23, 143-149. [CrossRef]

84. Rana, R.; Singhal, R. Chi-Square Test and its Application in Hypothesis Testing. J. Pract. Cardiovasc. Sci. $2015,1,69-71$.

85. Landau, S.; Everitt, B.S. A Handbook Of Statistical Analyses Using SPSS; Chapman \& Hall: New York, NY, USA, 2004.

86. Nachar, N. The Mann-Whitney U: A Test for Assessing Whether Two Independent Samples Come from the Same Distribution. Tutor. Quant. Methods Psychol. 2008, 4, 13-20. [CrossRef]

87. Fay, M.P.; Proschan, M.A. Wilcoxon-Mann Whitney or t-test? On Assumptions for Hypothesis Tests and Multiple Interpretations Of Decision Rules. Stat. Surv. 2010, 4, 1-39. [CrossRef] [PubMed]

88. Shapiro, S.S.; Wilk, M.B. An Analysis of Variance Test for Normality (Complete Samples). Biometrika 1965, 52, 591-611. [CrossRef]

89. Hayes, A.F. Introduction to Mediation, Moderation, and Conditional Process Analysis: A Regression-Based Approach; Guilford Publications: New York, NY, USA, 2017.

90. Kossek, E.E.; Su, R.; Wu, L. “Opting Out” or "Pushed Out”? Integrating Perspectives on Women's Career Equality for Gender Inclusion and Interventions. J. Manag. 2017, 43, 228-254. [CrossRef]

91. Williams, J.C.; Berdahl, J.L.; Vandello, J.A. Beyond Work-Life “Integration”. Annu. Rev. Psychol. 2016, 67, 515-539. [CrossRef]

92. Bem, S.L. Sex-Bole Inventory; Consulting Psychologists Press: New York, NY, USA, 1981.

93. Eagly, A. Women as Leaders: Leadership Style versus Leaders Values and Attitudes. In Gender and Work: Challenging Conventional Wisdom; Ely, R., Cuddy, A., Eds.; Harvard Business School Press: Boston, MA, USA, 2013; pp. 4-11.

94. Tharenou, P.; Latimer, S.; Conroy, D. How do you Make it to the Top? An Examination of Influences on Women's and Men's Managerial Advancement. Acad. Manag. J. 1994, 37, 899-931.

95. Kirchmeyer, C. Determinants of Managerial Career Success: Evidence and Explanation of Male/Female Differences. J. Manag. 1998, 24, 673-692. [CrossRef]

96. Tharenou, P. Going up? Do Traits and Informal Social Processes Predict Advancing in Management? Acad. Manag. J. 2001, 44, 1005-1017. [CrossRef] 